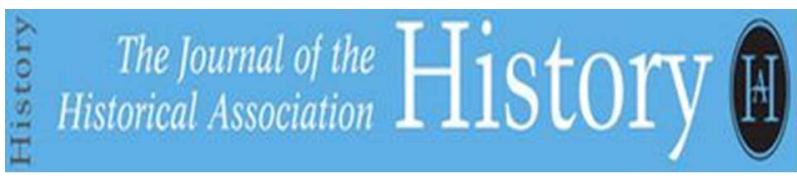

\title{
German Soldiers and the Horror of War: Fear of Death and the Joy of Killing in 1870 and 1914
}

\begin{tabular}{|c|l|}
\hline Journal: & History: The Journal of the Historical Association \\
\hline Manuscript ID & Draft \\
\hline Wiley - Manuscript type: & Special Issue \\
\hline Abstract: & $\begin{array}{l}\text { This chapter investigates the relationship between the legitimization of acts } \\
\text { of aggression in wars and the outlawing of violence at home. It focuses on } \\
\text { soldiers' responses to violence during the transition from nineteenth- } \\
\text { century warfare to total war, which relied not only on mass conscription } \\
\text { but also on the mobilization of civilians. In the 'wars of the masses' of the } \\
\text { late nineteenth and early twentieth century - the Franco-German War } \\
\text { (1870-71) and the First World War (1914-18) - large numbers of } \\
\text { individuals were required to kill on behalf of the state. For 'more developed } \\
\text { industrial states', this was the point at which, as Norbert Elias recognized, } \\
\text { 'the gradient between pacification within the state and the threat between } \\
\text { states is often especially steep.' Soldiers were thus caught between a taboo } \\
\text { on aggression and killing in civilian life, and the encouragement and } \\
\text { rewarding of violence during wartime. The article points to important } \\
\text { similarities between combatants' responses in 1870 and 1914 whilst also } \\
\text { accepting that the inhibition of aggression had become more pronounced } \\
\text { by 1914, despite more widespread expressions of national feeling, which } \\
\text { served to legitimize the violent actions of conscript soldiers. At the same } \\
\text { time, the reversal of civilized norms took place quickly during modern wars } \\
\text { and with lasting effects during peacetime. Under certain conditions, acts of } \\
\text { violence, the prohibition of which was supposedly necessary for the very } \\
\text { existence of civilized societies, were rapidly accepted as a part of warfare } \\
\text { and seem subsequently to have been accepted by sections of civil society. }\end{array}$ \\
\hline
\end{tabular}




\title{
German Soldiers and the Horror of War: \\ Fear of Death and the Joy of Killing in 1870 and 1914
}

\author{
Mark Hewitson
}

In the aftermath of the First World War, there were many conflicting accounts of what had just happened. One of the most pressing questions concerned the effects of combat on the millions of soldiers who had experienced industrialized warfare and who were now returning home. ${ }^{1}$ When they looked back, novelists such as Ernst Jünger and Walter Flex, who re-mythologized war and resurrected military values, disagreed fundamentally with opponents like Erich Maria Remarque, who exposed the absurdity, repulsiveness and arbitrary violence of the trenches, where 'men go on living with the top of their skulls missing, ${ }^{2}$ Paul, the middle-class schoolboy-turned-soldier and narrator of Im Westen nichts Neues (1929), is alienated and repelled by combat, believing that 'Everything must have been fraudulent and pointless if thousands of years of civilization weren't even able to prevent this river of blood, couldn't stop these torture chambers existing in their hundreds of thousands. ${ }^{3}$ By contrast, Jünger, a real schoolboy from Hanover who volunteered in 1914, felt vindicated by the conflict: 'We stood with our feet in mud and blood, yet our faces were turned to things of exalted worth."

What united such literary and visual representations of war, in Joanna Bourke's opinion, was their manifest fascination with acts of violence and killing, echoing or reversing many of the tropes of dominant patriotic and heroic depictions of combat. ${ }^{5}$ 'Anti-war films simply relocated the conflict and quickly re-entered the romanticized canon of war,' she contends of twentieth-century accounts: 'Realistic representations of combat are not necessarily pacifist or even pacifistic. It was precisely the horror which thrilled audiences and readers [-] gore and abjection was the pleasure subverting any antiwar moral. ${ }^{6}$ Authors of previous conflicts such as Theodor Fontane and Felix Dahn, who described the Franco-German conflict of 1870-71, betrayed a similar fascination. 'War', wrote the latter, 'makes warriors wild', unfettering 'the sleeping, ravenous animal in 
humanity', yet this unleashing of bestiality did not bring military intervention into disrepute. ${ }^{7}$ Rather, 'we recognize with Moltke that the terrible calamity of war, besides damaging influences on morality, also has the great effect of inspiring people to the highest act of virtue. ${ }^{8}$ These literary portrayals of warfare were interwoven with a ubiquitous mythology of chivalrous and heroic killing. Thus, at the start of the First World War, the young British aristocrat and officer Julian Grenfell, crawling to within ten yards of a German trench, was happy to confirm that 'It was very exciting'. 9 Sniping was like hunting, just as aerial combat was akin to a duel, 'a romance' or an 'epic', recalling 'the old legends of chivalry', in David Lloyd George's words. ${ }^{10}$

Although their sensibilities were complicated by the diverse conditions of combat and contradictory feelings towards the enemy, soldiers regularly enjoyed killing, in Bourke's view. 'I had thought myself more or less immune from this intoxication until, as trench mortar officer, I was given command over what is probably the most murderous instrument in modern warfare,' wrote the maverick Belgian socialist and Frankfurt academic Henrik de Man: 'One day ... I secured a direct hit on an enemy encampment, saw bodies or parts of bodies go up in the air, and heard the desperate yelling of the wounded or the runaways. I had to confess to myself that it was one of the happiest moments of my life. ${ }^{11}$ In response to the substantial evidence provided by American studies during and after the Second World War, which suggested that the majority of combatants found killing difficult, Bourke questions the investigators' basic research, contending that S. L. A. Marshall - in Men Against Fire (1947) - 'did not interview as many men as he said he did, and not one of the men he interviewed remembered being asked whether or not he fired his weapon'. ${ }^{12}$ She also asks whether Marshall's explanation for 'men's passivity in battle' was not the consequence of its long range, where soldiers were 'unnerved' by the feeling that they were 'fighting phantoms' who did 'not seem to be present'. ${ }^{13}$ In closer combat, soldiers found it easier to kill, especially those with the most extensive training who had used 'sacks for dummies', filled 'to give the greatest resistance without injury to the bayonet' and to create 'a realistic effect, ... as if gripped by a bone', as the 1916 British Army manual phrased it. ${ }^{14}$

Despite the fact that Samuel Stouffer's study of The American Soldier (1949) was conducted on behalf of the Research Branch of the Army Information and Education 
Division in order to discover why so many soldiers deserted before embarkation and why morale in the infantry was a constant problem, Bourke concentrates on the role of 'love' and 'hatred', often racial, in the killing of enemy troops: from the 12,000 GIs interviewed and half a million surveyed, about one-third confessed to feelings of hatred as a motivation, with between 38 and 48 percent of soldiers predicting that they would enjoy killing Japanese opponents; over two-thirds of troops before embarkation wanted the Japanese people to be 'wiped out altogether' and over a third desired the same for the German people. ${ }^{15}$ This figure dropped to about a quarter of American troops fighting in Europe who desired the annihilation of the Germans and more than 40 percent of US troops in the Pacific hoping for that of the Japanese. Stouffer's main finding - notably, that 'primary group' loyalty enabled combatants to keep fighting in difficult circumstances - is mentioned only in passing. ${ }^{16}$ Instead, once the trappings of 'civilization' were stripped away, as the exiled Jewish-German sociologist Norbert Elias had predicted in 1939, soldiers revealed the violent 'pleasures of life' - 'rapine, battle, hunting of men and animals' - which had been characteristic of ancient and 'simpler societies'. ${ }^{17}$ Like William James, whose contention in 'The Moral Equivalent of War' (1910) that 'pugnacity' had been 'bred into our bone and marrow' and would not be bred out of it by 'thousands of years of peace' is quoted approvingly by Bourke, Sigmund Freud - who is not cited - was convinced during the First World War that the 'brutality shown by individuals' was an expression of primitive impulses which had not been displaced by higher ones but which coexisted with them. ${ }^{18}$ 'When the furious struggle of the present war has been decided, each one of the victorious fighters will return home joyfully to his wife and children, unchecked and undisturbed by the thought of the enemies he has killed, whether at close quarters or at long range,' prophesied the psychoanalyst. ${ }^{19}$ Despite acknowledging that 'coming home from the battlefield was never easy, even for those men and women who told their combat stories in constructive ways,' Bourke broadly confirms Freud's prediction that returning to civilian life was easier than expected. ${ }^{20}$

This study re-assesses the causes, stages and significance of combatants' responses to modern warfare, taking issue less with the contention that the majority of soldiers enjoyed - or were relatively untroubled by - killing, which has been the focus of much 
recent research, than with the supposition that killing itself was central to troops' reaction to combat. Elias's work is significant in this context, since it suggests that soldiers would not find it straightforward to ignore civilian taboos on killing or to accustom themselves to the sight, sound, odour and touch of dismemberment and death. The establishment of 'pacified social spaces' in civilized societies had not only entailed the punishment of 'socially undesirable expressions of instinct and pleasure' - including acts of violence 'with measures that generate and reinforce displeasure and anxiety', they had also reduced civilians' experience of the consequences of such expressions and acts. ${ }^{21}$ 'The pleasure of physical attack' was permitted only during revolutions or wars, in which 'the gradient between pacification within the state and the threat between states is often especially steep. ${ }^{22}$ However, the removal of civilized constraints could only be gradual. 'If one inquires into the conditions in a society under which civilized forms of behaviour and conscience begin to dissolve, one sees [that]...it is a process of brutalization and dehumanization which in relatively civilised societies always requires considerable time,' concludes the sociologist: 'In such societies, terror and horror hardly ever manifest themselves without a fairly long social process in which conscience decomposes. ${ }^{23}$ Modern warfare did not always require or produce this decomposition, having become 'impersonal', with 'invisible' enemies and 'a mechanised struggle demanding a strict control of the affects. ${ }^{24}$

More importantly, civilians-as-soldiers were not used to the prospect of the maiming and death of themselves or others, as Julian Grenfell revealed in his letters home. He was content, perhaps unusually as a professional soldier and a keen huntsman, to kill German soldiers as a form of sport: 'I saw his teeth glisten against my foresight, and I pulled the trigger very steady. He just gave a grunt and crumpled up. ${ }^{25}$ Grenfell was delighted to be on a campaign: 'I adore war. It is like a big picnic without the objectlessness of a picnic. I've never been so well or so happy. ${ }^{26}$ Yet he was unsettled by the bloodshed of the conflict: 'I longed to be able to say that I liked it, after all one has heard of being under fire for the first time. But it's bloody. I pretended to myself for a bit that I liked it; but it was no good'. ${ }^{27}$ Most other troops, especially raw conscripts and volunteers, were much more unsettled than Grenfell. Here, I compare German soldiers' reactions to the different technologies of killing and conditions of combat in 1870-71, in a victorious war, and in 
1914-18, in a conflict which ended in an acrimonious and contested defeat, in order to understand how, why and to what extent they became disillusioned with modern warfare.

\section{Germany and the Next War}

The causes of soldiers' disillusionment are contested. In the literature on the First World War, there has been an understandable emphasis on the war of attrition, slowly wearing troops down, the conditions of life in the trenches, the effects of sustained and apparently arbitrary artillery barrages, high killing rates during senseless advances into barbed wire and machine-gun fire, and the cumulative effects of extended periods in the man-made wasteland of war at the front. ${ }^{28}$ Contemporaries' visual and literary depictions of the conflict, together with the historiography of such sites of memory, have tended to reinforce this impression, alternating between acts of killing and exposure to carnage and the risk of death. ${ }^{29}$ Even Paul, Remarque's archetype of a once-inflamed, now disillusioned middle-class volunteer, conflates dying and killing within an indistinct and inescapable process of brutalization, as combatants, reaching 'the zone where the front line begins, ... turned into human animals'. ${ }^{30}$ Such soldiers were dangerous, not because they had suffered unimaginable hardship but because they had become brutish killers: 'We were eighteen years old, and we had just begun to love the world and to love being in it; but we had to shoot at it. The first shell to land went straight to our hearts. We've been cut off from real action, from getting on, from progress. We don't believe in those things any more; we believe in the war. ${ }^{31}$ Shells had pierced the hearts of combatants, causing them to shoot at the world, not to love it. Kropp confirms Paul's fears of the postwar consequences of such alienation: 'I wonder whether the people back at home don't worry about it themselves occasionally? Two years of rifle fire and hand-grenades - you can't just take it all off like a pair of socks afterwards'. ${ }^{32}$ The soldiers here are at once facing rifle fire and grenades and throwing the hand-grenades and firing the rifles themselves.

Historians have made similar assumptions, influenced by a focus in studies of the Second World War and Vietnam on perpetrators and killers, or what Samuel Hynes - 
citing Leo Tolstoy - calls 'the reality of war, the actual killing': 'I was more interested to know in what way and under the influence of what feeling one soldier kills another than to know how the armies were arranged at Austerlitz and Borodino. ${ }^{33}$ At the centre of Alan Kramer's 'dynamic of destruction' in and after 1914, 'which produced the most extensive cultural devastation and mass killing in Europe since the Thirty Years War', is the relationship between 'ordinary soldiers who suffered violence and were agents of violence' and 'commanders and politicians, who were the decision-makers with the power to modify the process'. ${ }^{34}$ Yet what if the assumed linkages between the suffering and exercise of violence were less clear-cut than is often supposed? The question of how soldiers were broken, damaged and disillusioned by the First World War has implications for their subsequent behaviour and reintegration in peacetime.

There is evidence to suggest that the shock of modern warfare was quick and decisive, with the majority of combatants in both the Franco-German War and the First World War experiencing similar types of reaction during their first exposure to combat. In this early phase of fighting, the conditions faced by troops in 1870 and 1914 were similar in important respects. The largest opening battles of the First World War - Liège on 5-8 August (5,300 Germans killed), the Ardennes on 21-23 August (38,000), the Sambre on the same date $(15,000)$, Tannenberg on 26-30 August $(14,000)$ and the various battles on the Marne on 1-10 September (67,700) - were comparable to those of the Franco-German campaign, with 10,500 German dead at Froeschwiller on 6 August 1870, 35,943 at Marsla-Tour and Gravelotte on 16-18 August, and 9,000 at Sedan on 1-2 September. ${ }^{35}$ The rate of killing - at between 0.4 and 0.8 percent of the total number of soldiers per month - was not dissimilar to that of the first month of the Franco-German War. ${ }^{36}$ Moreover, in the autumn of 1914, before the heaviest casualties had been sustained, most combatants believed that the conflict would be over by Christmas. The conditions which they experienced, when the fighting front was still mobile and trench warfare in winter unimaginable, were outwardly not so different from those of other nineteenth-century wars. On the Eastern Front, where heavy artillery and attrition played a less conspicuous part, such conditions persisted for even longer. As a consequence, it is possible, with appropriate qualifications, to compare soldiers' reactions to violence and death in 1914 with their predecessors' responses in 1870. 
Soldiers went to war in 1870 and 1914 with a variety of expectations. Many officers and middle-class volunteers - but not all - dreamed of heroic deeds during what one Obergerichtsrat in Celle called - in the autumn of 1870 - 'these first mighty days'. 37 'I cannot describe it', rejoiced one participant on his way from Berlin to the Rhineland, 'and I don't need to, for every German heart is filled with the same feeling, pushing everything else into the background. ${ }^{38}$ Some middle-class combatants in the FrancoGerman War, particularly those who had fought in 1864 or 1866 and those who came from the former 'enemy' states of the Third Germany, had more mixed feelings. 'In many respects, a certain tension between South Germans and North Germans' persisted, 'even during the campaign', wrote one army chaplain from Württemberg: 'There were so many 1866ers there from both sides, whose reconciliation against the common enemy lends itself poetically to really beautiful portrayals, but which in reality left much to be desired. ${ }^{39}$ In autumn 1914 (and even more so after that date), middle-class conscripts' fearful premonitions of modern warfare were more widespread than in 1870. Admissions like that of one student volunteer (in a letter to his mother written on the train to France in September 1914) that 'war is a very, very evil thing' were rare in earlier German conflicts. $^{40}$ As another student expressed it in August 1914, before going to the front: 'Every soldier must, to start with, be, as I was a week ago, oppressed by the first mental picture of horrors which are no longer mere possibilities, but actually approaching realities; and on the day of the first battle the feeling of dread is bound to try and get possession of one's heart again. ${ }^{41}$ Even for Junker officers such as Wilhelm Freiherr von Richthofen, 'enthusiasm is not predominant amongst us, but rather nausea before [the prospect of] war. ${ }^{42}$

The majority of ordinary soldiers in 1914 seem to have shared such feelings, albeit mixed with an anticipation of adventure. 'During mobilization, as the last thread of hope was severed, it became even quieter and desperation set in,' recorded one clergyman from a Hessian industrial village: 'Of the mood during their departure, I can only say that everything was truly desperate, with many tears at home and in the church. ${ }^{, 43}$ 'Everywhere' in the agricultural region of southern Bavaria, wrote one teacher, the declaration of a state of war has caused great dismay in every quarter'. ${ }^{44}$ In 1870 , the reaction was similar. 'They naturally were more inclined to see the worst, that which 
pressed and menaced themselves and their families amidst such rapid movements of events over the last few days,' wrote Friedrich Rückert, from Hesse-Darmstadt, of the reaction of 'ordinary people' (die einfache Bevölkerung) to the outbreak of hostilities: 'The political scope and substance of the coming events was mostly still incomprehensible for them. They held this war too, like every other one, to be a serious misfortune, which intruded into their Heimat and well-being' ${ }^{45}$ In villages like that described by Leonard Heiners, near to Trier, opposition and foreboding were much more openly expressed: during mass, 'no, I have never experienced such a thing, and I'll never experience it again. Women wailed loudly. Pastor Antwerpen was himself scarcely in a state to bring the mass to an end. After communion, he wanted to give a speech, but impossible. Tears ran down his cheeks and his throat was if it was being choked.... On the parade ground, the scene was heart-breaking. ${ }^{46}$ In Dresden railway station, the mood was 'flat', before 'numerous but silent spectators', whilst in Berlin, the send-off was 'uneasy and oppressive', with 'no happy laughing, no brave joke'. ${ }^{47}$ Such soldiers did not know what to expect of war.

As they made their way towards the fighting, troops in 1870 betrayed little sign of foreboding. The reports of ordinary soldiers, like that of Joseph Hesse, give the impression of merely being shunted from one place to another: 'On 21 July, we moved from Hanover to Anderten, where we stayed until the $30^{\text {th }}$; then we went to Bingen, where we arrived on the $31^{\text {st }}$, and from there we marched to Lauheim, where we stayed the night. ... On the $15^{\text {th }}$ [August], we came to Ponte-Muoson ( $\left.\mathrm{sic}\right)$, where we were woken by an alarm at 3 o'clock, and from there marched to Marslatour, where we entered battle around 3 o'clock. In the evening, we went to a bivouac, on the $17^{\text {th }}$ we had a rest. On the $18^{\text {th }}$, we came under fire again near Gravelotte, we went to a bivouac in the evening, where we stayed for two days. ${ }^{48}$ 'The days', wrote another conscript in early August, 'are too long', filled with wearisome marching and other tasks from before dawn until nightfall. ${ }^{49}$ Although middle-class volunteers sometimes made similar complaints, they were generally more idealistic. Thus, even after viewing the battlefield of Wissembourg, the Bavarian maths student and trainee teacher Edmund Metsch felt 'brave like a man' and was confident that he 'would fight for the home of my loved ones and for my dear, beloved fatherland', as he marched towards Wörth, admiring the beautiful 
landscape and thinking about 'home, his parents and siblings, relatives and beloved friends' ${ }^{50}$

After fighting at Froeschwiller, the Bavarian volunteer Florian Kühnhauser remembered 'this ghastly, beautiful view of the turmoil of battle', as he had approached, despite having spent the previous night - his first in France - under the rain, 'in excrement and dirt'. ${ }^{51}$ Almost immediately, however, he and his company were surrounded by the sensations of combat: 'Was it another storm coming? No, it was the thunder of cannon; the battle near Wörth had already begun. Deep earnestness was visible on every face. ${ }^{52}$ Kühnhauser's mind was 'not able to comprehend each moment, for there is no time to look or to think', as the command to go 'forwards, forwards' resounded. ${ }^{53}$ Likewise, Metsch quickly forgot extraneous thoughts of home or heroism as he passed rows of dead soldiers, 'their gaping wounds visible to my eye' and with 'no mourning heart' to cry 'over their corpses', and made his way to battle. ${ }^{54}$ 'No one will forget the great view of the battle of Wörth, which had already begun, as we marched down the hill into the encounter,' he wrote: 'One's chest rose up and one's heart knocked against one's breast with tempestuous beats. The small-arms fire was so violent that it was not possible to distinguish individual shots from one another. In between, the peculiar "rrrt" which was made by the mitrailleuses, in addition to which the heavy guns bellowed out their thunder incessantly. ${ }^{, 55}$ Irrespective of their feelings beforehand, most combatants found that they were drawn - or pushed - into battle in this way.

In August and September 1914, soldiers' experiences of mobilization and deployment were fundamentally similar to those of their predecessors. It is true that some middleclass conscripts and volunteers had more elevated, almost millenarian, hopes of the war, frequently combined with a dread of the modern conditions of combat. 'I mean to go into this business “like Blücher",' wrote Walter Limmer, a law student from Saxony, on 7 August 1914: 'And this feeling is universal among the soldiers .... we were so full of excitement, fury and enthusiasm. It is a joy to go to the front with such comrades. We are bound to be victorious! ${ }^{56}$ Yet he also admitted in the same letter that he was oppressed by the 'horrors' associated with the reality of war. ${ }^{57}$ 'Our march to the station was a gripping and uplifting experience!' he reported: 'Such a march is hallowed by its background of significance and danger. ${ }^{58}$ The 'excitement' of the march to war for such 
soldiers was informed by an oscillation between hopes of glory and the anticipation of dismemberment and death: 'This hour is one such as seldom strikes in the life of a nation, and it is so marvelous and moving as to be in itself sufficient compensation for many sufferings and sacrifices,' Limmer had noted in the train to the western front. ${ }^{59}$

One month later on 9 September, Limmer's tone was quite different, noting simply that battle was 'ghastly' and artillery fire 'appalling'. ${ }^{60} \mathrm{He}$ had been engulfed by sights, sounds and smells of warfare which he attempted to dig his way out of, creating 'a sort of grave-like hole ... in the firing line', and which a soldier would have been relieved, 'thanks to the special mercy of God, if [he] comes out of it safe and sound' ${ }^{61}$ By 20 September, he was on his way home, injured: 'Oh, how happy I am to see a brighter world again, instead of that world of horror! At last I am free from that secret dread which always haunted me, that I should never see you and your world again', he confided to his parents and siblings. ${ }^{62}$ He died four days later of tetanus. As soon as he experienced combat, his earlier hopes and fears seem to have evaporated in what one reserve officer, who had noted the 'unspeakable enthusiasm' and the atmosphere of 'an agreeable rustic picnic' of the German deployment, a few weeks later called 'the ravaging traces of war'. 63 'How many wars, with murder, arson, nameless unhappiness and misery, must you look upon and will you have to look upon in future in the course of your life!' asked the reserve officer - Arthur Schicht - on 8 September from the eastern front: 'And these reflections of God throttle and tear each other apart in the most terrible war that the world has ever seen, which - in the annals of history - will bear the name - the war of madness. ${ }^{64}$ Such soldiers seem to have gone to war in a heightened state of excitement, expecting the worst and hoping for the best. Perhaps these contradictory feelings of elation deepened their subsequent despair, as they were replaced by their direct experience of the conditions of the fighting front. Yet they appear, at most, to have had a secondary, reinforcing effect, issuing in a series of reactions which were comparable to those of their less 'excited' forebears in 1870 and ordinary rural and working-class conscripts in 1914.

Many ordinary soldiers harboured far less inflated hopes of the conflict than those of Limmer or Schicht. The spies of the Hamburg political police reported during July and August 1914 that workers were appalled that they should 'give up [their] lives' because 
an 'Austrian heir has been murdered'. 65 'I'm happy that I no longer need to take part,' admitted one older worker to colleagues in a bar: 'For I have no desire to let myself be shot for others. ${ }^{, 66}$ Although police officers were reporting by September that 'the same people who, shortly before, greeted the "International" with hurrahs during protest marches' were now 'bubbling over patriotically' (which the officers could 'scarcely believe'), these new and mixed emotions were themselves quickly replaced by others. ${ }^{67}$ As Friedrich Worblewski confided to his sister from the Russian border on 1 August, 'Everyone is very anxious'. ${ }^{68}$ In some respects, German troops' viewed the deployment of 1914 as more routine than that of 1870, when many of those mobilized had travelled on a train beyond their locality for the first time.

Forty years later, when most conscripts had become used to the railways and had a better knowledge of the world outside their village or town, their experiences of going to war were less romantic and adventurous, despite the fact that 2,070,000 men, 11,800 pieces of artillery and 400,000 tons of supplies were moving towards the theatres of war in August and September on 20,800 trains. ${ }^{69}$ For Julius Lauth, for instance, deployment was merely a matter of changing trains. 'The journey from Osnabrück to Wesel and also to Essen is, according to my enquiries, still very roundabout and tiring at present, so that I have in the meantime had to give up my hope that you could visit me soon,' he wrote to his wife on 21 August: 'Hopefully, though, the rail connection will soon improve again' ${ }^{70}$ By October, the train journey had become more eventful, after proceeding 'well and peacefully' for much of the way, but only because it had extended into the war zone of northern France, where 'in some places the rails had been prised loose', bridges had been blown up and railway engines 'smashed', as a young Adolf Hitler, a volunteer in the Sixteenth Bavarian Reserve Infantry, recorded in his diary. ${ }^{71}$ Once they had disembarked, the troops - whatever their expectations - were thrust into the unfamiliar environment of battle, with its alien sensations. 'Dear parents', wrote Heinrich Maibaum on 19 October, 'as long as one only knows of war in theory, one imagines it to be quite unlike it is in reality., 'W2 'War is something quite terrible,' averred another soldier, who had been wounded, on 10 September: 'When one experiences what we have done, then it is much worse than it appears in newspapers. ${ }^{, 73}$ The maelstrom of the early fighting overwhelmed 
the majority of soldiers in both 1870 and 1914, transforming their experience of combat and marking their memories of war.

\section{Baptisms of Fire}

As German troops entered battle, they were - according to their contemporaneous records and later recollections - more concerned by the barrage of artillery, hail of bullets, the sight of the dead and wounded and their own preoccupation with death than with their physical ability and moral warrant to kill enemy soldiers. As one Saxon trainee teacher and ordinary conscript put it after the Franco-German War, combat had become more 'passive', requiring fortitude in the face of an often unseen threat:

Admittedly, the courage that the soldier of the modern army must show is of a different kind from that of our ancestors or that of Greek and Roman heroes. For the most part, it can only exist today in contempt for the risk of death; in modern battles, it only comes to a struggle of man against man in the rarest cases, for death-bringing bullets reach the majority beforehand from a great distance. Yes, in the battles of the last Franco-German war, many were wounded and killed without ever having seen a single enemy in the face. How should heroic attitudes manifest themselves here other than in the suppression of the fear of death? The weakest and militarily worst schooled man can be greater in this respect than many of gigantic stature who show themselves to be anxious and timid when they think of being shot dead from an unexpected position. I believe that I am right to designate the courage of our modern soldiers as a predominantly passive virtue.

Nevertheless, this type of heroism, too, deserves our respect, for it betrays a great strength of soul and self-control. It is question of struggling against the strongest internal urge of man, the urge for selfpreservation. $^{74}$

The need for - and regular absence of - contempt for the risk of death proved more important than the moral quandaries of killing in both 1870 and 1914. Soldiers' first exposure to such modern warfare - their 'baptism of fire' (Feuertaufe) - frequently proved decisive in shaping their attitude to and recollection of the war in its entirety.

Soldiers such as Metsch, who approached the battlefield of Froeschwiller on 6 August, found themselves suddenly in an alien and disorienting environment. 'The air was full of 
smoke and torn apart by millions of bullets; it was turmoil, as if the elements of the earth were going to split apart,' he wrote in his diary: 'I was able to watch this for a few minutes, then we went into the pandemonium, against the enemy. Bullets surrounded us like swarming insects, and only the cracking of trees and the collapsing of so many vital, healthy comrades showed that these insects were from another realm of nature. Branches fell down, cracking, and poor wounded soldiers twisted around sighing, groaning and pleading for help, wallowing in their own blood' 75 Although it was true that the troops kept pressing forwards, in the hope that 'the enemy must give way', 'the battle raged terribly', leaving the troops in disarray and most officers dead. ${ }^{76}$ As they came out of the wood, the German soldiers were repelled twice by an unseen enemy, 'who was probably entrenched'. 77 'Thousands of dead and wounded already covered the battlefield', as the French eventually retreated. ${ }^{78}$ One soldier had had his foot blown off, left dangling by threads of nerves; another had had 'the right side of his face torn away, from his eye to his chin. ${ }^{, 79}$

The carnage at Mars-la-Tour on 16 August 1870, after which there were 'thousands of dead and wounded', and at Gravelotte on 18 August, which even the War Minister Albrecht von Roon had feared would occasion 'a useless loss of blood', was much greater than at Froeschwiller (and the other battles of early August). ${ }^{80}$ A member of the Saxon Twelfth Corps described Gravelotte: 'On both sides, there must have been hundreds of cannon and hundreds of thousands of rifles caught up in this blood-work. ${ }^{81}$ As the soldiers approached, they thought that they were making 'world history' but their mood soon changed: 'To the right and left and in front of us, comrades suddenly collapsed.... It all happened very suddenly and unexpectedly and was, faced with an invisible enemy, quite eerie. It was, in its particular novelty, so surprising and forceful in the first half minute that the blood of one's heart stopped and a death shudder penetrated to one's innermost recesses. ${ }^{82}$ Such existential panic, however, was 'merely the first zone of hell', as in Dante's vision of it, followed by all manner of 'fire, blood, death and destruction', in the midst of which 'one's whole life flashes before one's soul at lightning speed', recalled the same soldier. ${ }^{83}$

The Rhinelander Leonard Heiners described a similar scene from a different vantage point, entering the fray in the late afternoon after waiting around in earshot of the 
'thunder of cannon'. ${ }^{84}$ 'On the battlefield, everything disappears,' he wrote in his diary: 'One thinks of nothing. ${ }^{85}$ When the troops advanced, the fusilier saw 'many fall or fly through the air after receiving a shot' ${ }^{86}$ The officers of his company were soon dead, leaving a lieutenant of the reserves alone, blabbering that 'I don't feel myself capable in this important moment of taking over the command of the company'. ${ }^{87}$ Scarcely ten minutes later, the corporal who had taken command fell 'in an arc-like movement, with five shots in the chest in an area the size of a hand'. ${ }^{88}$ Those 'actively participating in a battle' could not describe it - 'that is, its course and state of affairs' - but they could leave a record of their experiences: 'He can only recount what he has himself participated in'. ${ }^{89}$ Heiners's own account could seem ambivalent: he was impressed by the dutifulness of every soldier, allegedly 'infused with enthusiasm'. ${ }^{90}$ Yet he was also overwhelmed by the sensations of battle, which he could recollect - and could not banish - after the event; 'the persistent thunder of cannon from both sides, the peculiar rattle of mitrailleuse, the constant small arms fire of the infantry, the roar of the cavalry, the cries of pain of the wounded, the groaning of the dying'. ${ }^{91}$ Injured himself in battle, passing the 'most horrible night of my life' in a barn, Heiners continued to think of 'the sights of the battlefield', which 'cannot be described': 'They are too terrible. ${ }^{92}$ Like other soldiers on 16-18 August and on 1-2 September at Sedan, Heiners did not discuss killing but did report extensively on what it felt like to be shot at and to be surrounded by the injured and dying.

The experience of German combatants at the start of the First World War was similar to that of their predecessors in 1870. Later, such soldiers' early impressions of fighting were overlaid by their exposure to the realities of trench warfare. From a reading of their testimony, however, the decisive shift in attitude of most of those mobilized in August 1914 occurred before the war of attrition. "'War is a fearsome, raging terror",' noted one soldier in his diary after the battle of Liège on 6 August: 'We see with horror how this proverb has become true. One says that it is not possible to survive it, when one thinks of all the terrible hours which we have come through. ${ }^{93}$ 'It is horrible to see the torments, the indescribable injuries,' recorded the Protestant chaplain of the $6^{\text {th }}$ Bavarian Reserve Division from Flanders on 2 November: 'it is horrible to see how the strife has not gone on for long, yet has shattered the hearts [of the troops]. ${ }^{, 94}$ Combat lifted the crushing 
weight of anxiety before battle, hinted one lawyer in a letter to his wife on 13 August, but it also gave way to other more powerful and enduring emotions, which stayed with soldiers long after the fighting: 'Fliers above us, columns beside us, often for hours, then sometimes a burning village, sometimes shrapnel, sometimes infantry fire. Are you shaking for the state of my nerves? They have been blown away! The headaches, too! The other gentlemen of our automobile corps, who as civilians were very nervous, have made the same extraordinary observation. ${ }^{95}$ Although he was pleased that his initial apprehension had been dispelled, the lawyer was experiencing a common progression from angst via immersion in the all-consuming moments of combat to nervous exhaustion, disgust at the slaughter of the battlefield, reluctance to fight again and concern about a gradual hardening of a soldier's sensibilities.

Each soldier's feelings differed, with some more matter-of-fact than others and some drawing greater strength than others from the justice or necessity of their cause. The reserve officer and painter Arthur Schicht was convinced at the beginning of September 1914 that 'holy Germany', 'the principal Kulturvolk in the world', was 'not to be destroyed' by an evil alliance of the 'main powers of Europe and Japan'. 'E6 'Every one of us who stands on the field gladly gives his life for the defence and protection of the fatherland,' he wrote from the eastern front, as 'we moved towards the enemy'. ${ }^{97}$ Yet Schicht was also profoundly aware of the 'devastation and cruelty' of the war, describing it as 'a peculiar feeling when one stands for the first time under fire and the bullets are whistling over your head'. ${ }^{98}$ Ordered to advance, the battalion met with 'the full rage of enemy fire': 'The particular clap and sighing of artillery shells, the whistling and banging of infantry fire, of machine guns, certainly agitated the nervous system in the first moments, but one quickly got used to the unfamiliar and peculiar situation, which brought us heavy losses through lively flanking fire from the right and shrapnel from the left and front. 99 Although he hoped that his uncle - an old officer - would be proud of his conduct ('I behaved well'), his mood was depressed as he saw the wounded after the battle: 'The groaning and pain ripped open my heart so that I could not open the eight items of post that had arrived; I felt so exhausted and assaulted by everything that had happened to me on this hot day. ${ }^{, 100}$ His outlook darkened over the next weeks: by 19 October, he was referring to the war as a 'terrible struggle of murder'; by 1 December, 
'the war' was 'endlessly inuring us to everything - one thinks of hardly anything else other than eating and sleeping'. ${ }^{101}$ The sense that one soldier on the western front had, later in the war, that 'It is best to believe in nothing at all and to live with dulled senses like an animal' was also widespread at the start of the campaign. ${ }^{102}$

Such references to animal-like responses were not restricted to the troglodyte life of the trenches. On the eastern front, the mobility of which - in some sectors - resembled that of the Franco-German War, soldiers' reactions to violence were indistinguishable from those of their counterparts on the western front. In his diary, a former supporter of the war described how the mood of his comrades had altered after the first encounters. 'Many of the young war volunteers cursed under their breath or whimpered quietly', he recorded in September 1914, 'and their enthusiasm was extinguished long ago.' ${ }^{103}$ They had volunteered 'to fight and die for a great cause', 'but the battle of bullets and bayonets is not as easy as that of words, and actual death out here is much more difficult and agonizing than that imagined on paper or in the theatre. ${ }^{104}$ Only two months after the start of the war, there were only a very few 'strong ones' left, including the author himself, 'for whom it is still a matter of great, bloody seriousness, for whom German idealism has not gone up in smoke'. ${ }^{105}$ By early 1915 , those unaffected by the violence were depicted as pathological. 'There are very few, but they do exist, and a good percentage of them are born criminal types who lived in constant conflict before the war with all human institutions and orders and for whom prisons are very familiar. ${ }^{106}$ 'These men', the diarist continued, 'are fully independent of life and death, and are as indifferent towards one as towards the other. ${ }^{\prime 107}$ For the majority of troops, however, their 'nerves are so overwrought that one takes the surprised chirping of the forest birds as the whistling of bullets, and sees old tree trunks in the darkness as enemy posts. ${ }^{108}$ Many officers as well as men threw themselves to the ground and rolled their eyes in fear at the slightest sound. For the rest, only a sense of duty, honour and courage prevented such insane behaviour. 'Imagination has reached the point at which it can easily turn into an illness', the soldier concluded. ${ }^{109}$ In the East as well as in the West, the effects of war were so extreme that they were rapidly pathologised by the soldiers themselves. In many instances, it seemed that conflict made combatants mentally ill. Even in these cases, though, 'criminal types' 
were marked out by their 'independence' of life and death more than by their acts of killing.

When correspondents and memoirists did occasionally refer to killing, which they did more frequently in 1914 than in 1870, they usually depicted it as the consequence - even as a by-product - of a confrontation with enemy artillery, unidentifiable small-arms fire, wounding and death. Soldiers had been turned into 'living numbers and shooting machines', according to the same diarist on the eastern front in August 1914, but only in the context of a 'remarkable war, in which one sees nothing of one's opponent': 'No, this is not an honest fight but completely vulgar, illicit murder. ${ }^{110}$ As the volunteer Heinrich Maibaum testified, the reality of warfare displaced earlier reservations about killing, with the transition from receiving to giving fire - often against an unseen enemy - barely noticed. 'I openly confess that I had doubts about how I would bear up when ordered to kill people,' he wrote to his parents on 19 October from the western front: 'But I assure you that it all happens automatically. In the moment when enemy bullets whizz over your head, when you see comrades falling beside you, the valves of the heart - which had previously been open to the slightest stimulus - close and the urge for self-preservation, anger and hatred alone say their piece and dictate our actions. ${ }^{, 11} 112$ Partly because it was reactive, partly because it was anonymous, killing was rarely alluded to in the correspondence and diaries of combatants. When they mentioned it, they generally did so in passing or without feeling, not - even tacitly - in enjoyment. 'It's my experience that I don't feel guilty, even when alone and in prayer, for having killed people,' admitted one soldier. ${ }^{113}$ 'The fact of the killing' was incontrovertible and the war was 'the product of the thousands of sins of us all', yet the commentator preferred to leave the question of guilt, in apparent indifference, to God. ${ }^{114}$ The tone of these diaries, in common with that of many others, is cynical and cold.

\section{Horror, Fantasies and Nerves}

It is possible that combatants were concealing their actual feelings during acts of killing. ${ }^{115}$ Their willingness to bring up the subject at all and to break other civilian 
taboos makes such a possibility unlikely, however. ${ }^{116}$ Depictions of the horror of war dated back to the civil strife of the Thirty Years' War and beyond, revived in the nineteenth century alongside depictions of the Napoleonic campaigns - especially the march to Moscow in 1812 - for a reading public. ${ }^{117}$ Over the course of the long nineteenth century, such depictions became less and less inhibited, betraying both changing conceptions of propriety and an unwillingness on the part of soldiers to embellish or conceal their wartime experiences.

Many correspondents in 1870 , it is true, continued to abide by standards of public decency, refusing to divulge what they had seen in battle. 'The peaceable burgher cannot even imagine it,' confessed a middle-class reserve officer: 'The impressions which I received here are too horrific for me to want to recollect them in all their details. ${ }^{118}$ Such discretion - as articulated in one later Justizrat's claim that 'I have seen scenes the description of which I shall spare you' - was almost routine. ${ }^{119}$ Nevertheless, some civilian-soldiers, often despite their best efforts, could not stop themselves from sharing what they had seen and experienced:

What a sight St Privat was! Is it even possible to give a description of such misery? The nearer we came to the north corner of the village (which had not been burned down), the more the bodies piled up, irregularly beside and on top of one another... The wounded had been gathered up from the battlefield and lay on the broad village street left and right, one placed close to the other on beds of straw. What a view, everywhere for 300 metres, complaining, moaning, twitching, dying people, some dumb and calm, others with their faces contorted and their limbs dislocated, these screaming loudly, those whimpering, isolated individuals striking their neighbours with fists and elbows in their struggle with death; and these sights! People suffering so! Staring blankly into the heavens, as if they were accusing the originator of the war, as if they were searching for something, perhaps thinking of their own; here, there was no friend and foe any more. Whoever says that war is beautiful did not see St Privat on 19 August!! ${ }^{120}$

Having seen one battlefield, most soldiers tried to avoid others, asserted one proud veteran. ${ }^{121}$ It is evident from his and other descriptions, though, that such scenes also fascinated and hardened those who witnessed them. 'It is not a nice sight, such a corpsefilled battlefield; yet people get used to everything,' noted one 'civilian' officer, who later became the warden of a workhouse: 'A corpse must contain a sort of magnetic force; at least, I did not manage simply to look away from those dead who lay in our way 
- I had to look at these poor, often really ugly, dismembered bodies. ${ }^{, 22}$ For such observers, the comforting defences, prohibitions and taboos of 'civilized' society had been breached.

Even noble officers, despite their self-discipline, sense of honour and anticipation of heroism, felt compelled to record their experiences in graphic and unflattering terms. Thus, although he had entered the conflict 'with joy' in July 1870 and had celebrated loading his gun for the first time at the battle of Froeschwiller (or Wörth) on 6 August, the Bavarian officer Dietrich Freiherr von Lassberg had come to alter his opinion of warfare over the following month. ${ }^{123}$ As the regiment had approached the battlefield, he had heard the 'eerie' sound of the French mitrailleuses in the distance and was eager to get closer. The first two casualties in his unit were almost cause to rejoice - 'the first wounded and the first dead in the company!!' - as he advanced into enemy fire, shells and bullets tearing up trees around him. ${ }^{124}$ During the fighting itself, corpses and injuries constituted part of the adventure, with little time to reflect and every incentive to act: 'from all sides, the horn and drum signal - "Forwards! Attack!"....wounded and dead French... wounded Turkos lying in their own blood. ${ }^{125}$ Yet the next day Lassberg was forced to face the consequences of such military action when he surveyed the battlefield, his tone becoming more muted: 'This great pile of dead - never had I seen so many corpses together - in the most diverse French uniforms, bloody, dusty, disfigured by burns from explosives, with limbs torn off, often half naked, hands regularly clenched convulsively, arms often stretched up stiffly, many with an expression of anger, many with one of pain... - this view was terrible and made... a deep and melancholy impression on us. ${ }^{126}$

On 1 September at Sedan, Lassberg witnessed more traumatic scenes as his regiment stormed a village. Despite participating in one of the most heroic assaults of the decisive battle of the war, after which Napoleon III was captured and the German Empire eventually created, Lassberg's descriptions were much more subdued from the start than they had been only a month beforehand. 'They were', he wrote, 'just some of the scenes in the horrible and bitter struggle', littered with 'burned or even roasted bodies'. ${ }^{127}$ To other officers, too, Sedan was 'in fact a terrible picture of destruction and annihilation', with the battlefield 'considerably different in character from that of St Privat': 'Here, 
death had laid out the field like a careful farmer and the corpses and debris were almost methodically divided equally over a great space'. ${ }^{128}$ A 'massive number of dead' could be seen, wrote the Prussian officer Kurt von Einsiedel: 'A new and peculiar sight for me was repeated regularly in truly terrifying images - these were groups of three or four corpses lying next to each other, which were half burned and with their naked and often green bodies, which in addition were torn apart by grenades and covered with blood, offering a terrible prospect'. ${ }^{129}$ During the 'great moment' of victory it seemed to Lassberg that 'after rain comes sunshine', but it was also evident, on inspection of the battlefield, that 'after sunshine comes rain':

Here one saw the smashed black head of a Turko and under him lay a Bavarian, whose chest had been ripped through by a full grenade; here lay a formless lump of flesh, which one could recognise as a fully shredded French soldier of the line; a grenade probably exploded the moment it hit him, as he was sitting or lying, and tore him up; elsewhere, one saw human bodies which one could have taken for mummies, and others which looked like charcoal....I'll refrain from giving further description, which in any case falls well short of reality. It was a terrible and, at the same time, deeply moving and unsettling view! These are the dark sides of war! It is nice to say of the soldier, and we soldiers like to hear this and say it ourselves: 'The most beautiful death is death on the battlefield' - but truly, the most beautiful dead are not the dead on the battlefield! And how much more do numerous artists fail, who give their dead such a beautiful and ideal appearance that one is almost tempted to wish oneself in their place! These beautiful, ideal soldiers' corpses do not exist. ${ }^{130}$

Like fellow officers, who saw their fantasies 'driven away' by such an 'atrocious reality', Lassberg was left, during such moments, facing an empty and comfortless existence. ${ }^{131}$ Only victory and unification seemed capable of restoring soldiers' good spirits. Even then, some found that their 'joy over the great victory was gone'. ${ }^{132}$

During the First World War, such accounts of the horror of war became commonplace. They were also more uncompromising and, paradoxically, more fantastical. Unlike in 1870-71, heroic elements were often removed entirely from correspondence, and relatives were rarely spared both a description of the combatant's crippling anxieties and a gruesome account of the atrocities of war. For many soldiers World War I proved so traumatic that they gave up their ideals and religious faith altogether, believing themselves abandoned in a godless and meaningless material universe. The majority of 
men in his regiment, noted a theologian, looked at the horrors of the conflict and asked disbelievingly whether 'there is meant to be a God here?' ${ }^{133}$ 'The earth is hot with violence,' wrote Bernhard von der Marwitz of the eastern front: 'Millions of soldiers march across this land to battle. But no one has a prayer. ${ }^{134}$ Combatants had been so disoriented by the sensations of dismemberment and death which they encountered that they frequently came to doubt their own humanity, perceiving themselves to be mere flesh or matter, even when a vestigial faith in God, or fate, remained:

If only the hand of God, which up till now has graciously led me unscathed through all the fatigues and dangers, continues to protect me, it shall not be my fault if I too am not a man when I come home. I am counting more than ever on that, for truly the war-horror seems to have reached its climax. O God! How many have those hours been when on every side gruesome death was reaping his terrible harvest. Ones sees someone fall - forward on his face - one can't immediately recognise who it is - one turns the blood-covered face up - O God! It's you! Why had it to be just you! And how often that happened! At such moments I had but one picture before my mind's eye. I saw you, my dear, good father, as you laid your blessing upon my head - beside your bed it was, on the morning when I thought I must go - and you prayed for God's mercy on me. ${ }^{135}$

Such disenchantment was visible, as in this case from September 1914, at the very beginning of the war, before shelling and attrition turned the landscape of Flanders and northern France into a physically inhuman space. Mental desolation often preceded physical destruction.

Having experienced mental trauma, which was itself partly the upshot of the disjunction between domestic pacification and international violence, soldiers were regularly astonished to find how easily 'civilized' norms could be overturned. Troops found that they became desensitized to their own pain and to that of others. 'We all become more or less callous and unfeeling out here in this horrible war; whoever does not goes mad in the most real and awful sense of the word', confessed one correspondent. ${ }^{136}$ 'After an attack in a trench with bombs and flame-throwers one's very soul is seared,' wrote a combatant on the western front:

By the time I was wounded my nerves were in such a state that I had to make a great effort to control myself even though it didn't hurt. 'There's no need to get in such a fuss, you silly ass!' the staff-doctor said, 
and no doubt he was quite right. One must keep perfectly calm in body and mind. Therefore instead of sympathising with the sufferings of others, I have become as one of them - looking on death with indifference because I myself may die at any moment, and no longer sickening at the sight of wounds and of dark-red blood on pale, yellowish skin. Pity must be left to the angels. ${ }^{137}$

Soldiers had 'no real feeling any more' for the 'horrors' of war, noted one officer, recounting the story of a regiment which left the rotting corpses of a dozen English soldiers just in front of their trench with the argument 'they are lying, unburied, very well there.. ${ }^{138}$ The hand from one of the two bodies which they had had to bury, since they had been lying in the trenches, had been left protruding from the grave. ${ }^{139}$

The distinction between fantasy and reality is unclear in such stories. Streams of consciousness were common, alternating between metaphor and impression. Combatants witnessed scenes that they could not believe were real, 'the most terrible things, which only a wild fantasy can depict'. ${ }^{140}$ 'Agitated fantasies' prevented soldiers from finding an inner calm, complained another volunteer. ${ }^{141}$ Attacks were carried out in a 'fever-fantasy': 'Earth, open up! Air, I have you again, tremendous, life-giving spring air! Sun, warming, comforting, why is your light so weak?! Why don't you donate more light to one whose own eyes are for the most part robbed of it?!' implored a veteran of the eastern front: 'Oh, you suffering, cruel people, you with your grenades, with your flame-throwers and all your devilish inventions, why must you blind me, burn and tear up my face, and put me amongst the marked ones, amongst the lepers?!' The soldier concluded his febrile description of an attack: 'Come, comrades, who dug me out of my grave, come and bury me again, for I want to die! ${ }^{142}$ Many diaries were broken down into fragments of impressions, imaginings and interpretations, merging with each other:

\section{March 1916, before Pontavert}

Went through the captured position. A swampy stretch of forest, consisting of shell-smashed trees and battered trenches, surrounds the hill. The whole place looks as if it had been ploughed up. Blown in dugouts. Huge shell-craters. Fragments of wood and clothing; corpses; rifles; knapsacks. A field and wood of horror.

\section{March}

Had a stiff job: getting ammunition and material into the line. Gas-shells polluted the air. Men got buried. Attempts at artificial respiration.... The strain on the nerves is terrible. Many break down altogether.... 


\section{March}

Relieved tonight. At last. We had cleaned up the battlefield fairly well. Sights which I shall never forget. Sickening - sickening is the only word. But it has to be.

\section{April}

Somme. The whole history of the world cannot contain a more ghastly word! All the things I am now once more enjoying - bed, coffee, rest at night, water - seem unnatural and as if I had no right to them. And yet I was only there for a week. Life is a gift. If only I had not seen all that....At the beginning of the month we left our old position....The last days had been stiflingly hot. Sooner than we expected we were in the thick of it....The gunners could no longer see or hear. Verey lights were going up along the whole front, and there was a deafening noise: the cries of wounded, orders, reports....Falling down and getting up again. Machine-guns were firing....Day melts into night. ${ }^{143}$

This blurring of fantasy and reality was reinforced by the war. Other reasons for the combination of irony, horror, fantasy and naturalism - including the photographic mediatization of warfare, the metamorphosing conventions of war literature, the impact of the avant-garde, the shifting ground of individual morality and respectable conduct are easy to identify but difficult to evaluate. What is certain, though, is that soldiers were much more likely throughout the First World War, including its early stages, to write about violence and their fantasies of violence than were their predecessors in previous wars.

It was an indication of the debilitating shock caused by sudden and unaccustomed exposure to violence that doctors and officers paid such great attention to the psychological consequences of combat. Up to five percent of casualties in the First World War - 600,000 soldiers in Germany - were admitted to be psychiatric ('war neuroses'), with men from the ranks typically becoming mute and motionless, and officers having trembling and stuttering fits. ${ }^{144}$ Many more cases, of course, were not reported. Although it is possible that such cases existed in wartime prior to 1914 , they were almost certainly much smaller in number and were not mentioned in private diaries or correspondence. From the first battles of World War I, both the authorities and soldiers themselves were aware of the importance of 'nerves' and 'the nervous system' to the war effort. ${ }^{145}$ Many wondered how their nerves could withstand what they had witnessed and what they still had to endure. 'One must develop nerves of steel here to confront the horrors of war with the necessary cold-bloodedness,' wrote one soldier home: 'I myself don't master my 
repertoire of feelings (Empfindungsklaviatur) sufficiently to take on board everything that happens with the calmness which life in war necessarily demands. Sometimes my nerves go on strike. ${ }^{\prime 146}$ A doctor who was diagnosed with a 'disruption of nervous activity', described how such breakdowns could occur:

I believe that it is not so much the exertions as all the horrors that I have experienced in the last months which has so shaken my health. It is fully incomprehensible to me how humanity can tear itself to pieces in such reciprocal mass murder. I cannot pretend to have been particularly resistant to the disgusting and horrible, but now it has finally come to an end. I am so tired and faint, and would prefer to go sleep and not wake up again, at least before peace comes to the country, or not at all. ${ }^{147}$

Such accounts, with their allusions to the 'horrors' of torn and rotting flesh, intimate that the regularity of nervous breakdown during the First World War was not simply the result of the increasing destructiveness of artillery rounds, which had directly physical and psychological effects, but also the corollary of heightened sensitivity to violence and the possibility of death on the part of many of the soldiers.

\section{Conclusion}

The duration and matériel of the First World War wore German troops down, making them more despairing and cynical than their predecessors in previous conflicts and, in a large number of cases, rendering them psychologically incapable of fighting. Historians have, with some justification, challenged the assumption that most soldiers were affected in such a profound way, pointing to a series of effective coping mechanisms and to the rotation of troops between duty on the front line and longer periods in the rear, in quieter zones and on leave. ${ }^{148}$ Nonetheless, many soldiers were mentally scarred by the Great War. There were far more victims in this sense in 1914-18 than in 1870-71, when a volunteer such as Dahn was keen not only to prove that 'never has a war been waged with such conscience-bound, strict maintenance of international law (Kriegsrecht) as the war of 1870 by the German side, especially in the first months', but also that the war had not horrified him. ${ }^{149}$ 'These pictures of horror did not shock' him, he maintained. ${ }^{150}$ 
Dahn's memoirs, which ended like many others with the pious hope that 'the terrible calamity of war' inspired people to the highest act of virtue ('death for the fatherland'), subverted the author's own patriotic message. ${ }^{151} \mathrm{He}$ was at once fascinated and repelled by what he had seen. 'The effects of the German grenades were horrible,' he reported, as he surveyed a battlefield in late August: 'In the first line of tents, I found five, in the second six, who had been laid out there by a single shot....the main projectile had landed on the very body of the middle one; he was charred from the waist to the knee, flesh and uniform burned to a cinder, the white bones stuck out into the air. The front part of the face and skull of another one had been ripped off, the back part full like a dish with blood and brain; the neck and head of a third had been simply sliced off the rump'. ${ }^{152}$ The writer's experiences at Sedan, after the excitement of battle, were even more gruesome. Collecting the wounded on the following day, he noticed that his foot pushed against 'something soft, black: I bent down - it was the top part of a skull with the entire crown; two steps away lay the trunk belonging to it. Many of the faces of the dead were distorted by pain or anger, the teeth biting the lips, fingers clawing the earth; the eyes mostly open, blankly, with a look directed towards the heavens. ${ }^{153}$ Despite his protestation of equanimity, he did concede to having been overcome by disgust (Ekel) of 'the most extreme' kind, provoked by the 'smell of blood and suppurating wounds'. ${ }^{154} \mathrm{He}$ had not refrained from revealing the 'terrors' of war, using the licence granted to soldiers and war correspondents to transgress the boundaries of good taste. Such transgressive description was no doubt designed to excite the author's readership. It also seems to have derived from Dahn's own experiences, which coincided with those of other diarists and correspondents. The fact that many other soldiers sought to spare their readers such horrors suggests that those who did break taboos about public decency did so in order to express - admittedly, with some exaggeration - what they had experienced and witnessed.

The number of explicit accounts of war increased markedly after 1914. By the time of the First World War, although the degree of their acquiescence and obedience was striking by the late twentieth-century standards of the West, recruits were prepared to voice their revulsion of warfare. ${ }^{155}$ Combatants were now more likely to criticise or circumvent orders and tasks that conflicted with their own expectations, norms and sense 
of self. Fantasy, introspection, isolation, communion with nature, revolt and brutality were different sides of a radical, expressive individualism - or 'crass egoism', as one combatant put it - which quickly came to distinguish the troops of 1914 from those of $1870 .{ }^{156}$ In this respect, literary representations of the conflict coincided with evidence from diaries and correspondence. Thus, the character of Paul in Remarque's Im Westen nichts Neues lives on the surface, as an 'animal' at the front, 'because it is the only way we can survive', and as a 'superficial joker and idler' behind the lines, yet he also exists in the depths, having experienced extremes and faced death. ${ }^{157}$ He withdraws into animal-like action or trance-like reverie, surrounded by sights, sounds and smells so violent that they cease to have an effect. His memories have two qualities: 'They are always full of quietness, that is the most striking thing about them', and 'They are soundless apparitions, which speak to me by looks and gestures, wordless and silent - and their silence is precisely what disturbs me, forces me to hold on to my sleeve or my rifle so that I don't abandon myself to this seductive dissolution, in which my body would like to disperse itself and flow away towards the silent powers that lie behind all things. ${ }^{158}$ Whereas Paul feels himself dissolving and yearning for death ('after that I remember nothing'), Dahn seems to recover his autonomy and his patriotic purpose. ${ }^{159}$ The fates of the two figures - one a literary fiction, the other the author himself - hint at soldiers' differing experiences of World War I and the Franco-German War.

The contrasting literary and artistic record of the two German wars (1870-71 and 1914-18) has obscured a critical similarity: namely, that soldiers' attitudes to combat were transformed in the early phase of the conflict, as combatants were overcome by the feeling that they were defenceless against barrages of artillery and a 'hail' of gunfire. This conclusion coincides with oral histories of recent wars, which have contended that reliable, long-term memories of combat tend to focus on the first weeks of a campaign, which are recalled with great clarity, not on the later stages of campaigns (when the loosening of moral norms and the commission of atrocities frequently occur), which are much hazier in veterans' minds. ${ }^{160}$ Virtually all combatants were affected in 1870 and 1914 by the alien sensations of modern warfare (the smell of putrefying flesh, the sight of severed body parts, the touch of a corpse), depending on the conditions which they faced, 
but those who had been most insulated from such sensations in their civilian lives and who had had the least extensive military training seem to have been most affected.

In 1870, middle-class volunteers and reserve officers, who together composed much of the published account of the conflict, appear to have been most disturbed by battle. In 1914 , the pool of those fundamentally unsettled by their exposure to combat, some of whom went on to publish their own testimony of it, was much larger. Beyond these articulate witnesses of war, who were willing to disclose the 'dark sides' of conflict, were ranks of ordinary conscripts, whose reactions were detailed in the millions of letters and postcards - 89,659,000 between July 1870 and March 1871 in the North German Confederation alone - sent by Feldpost. ${ }^{161}$ Though more matter-of-fact, these soldiers, too, were marked by their experiences of combat, often with less - in patriotic or national terms - to sustain their war effort than was the case with their counterparts from the Bürgertum. Rather than enjoying the campaign - or the act of killing - such troops generally longed for it all to be over, even if they subsequently fashioned stories of a good war for their friends and relatives at home. Their testimony at the time and afterwards suggested that they had been shocked by the realities of modern warfare. Such wartime experiences, which were regularly kept private, informed their later skepticism of future conflicts. A few, it is true, had become killers, accustomed to the use of violence and proving difficult to reintegrate into civilian society, occasionally preferring the Foreign Legion or the 'Wild West' in the 1870 s and drifting towards the milieu of paramilitary politics and the Freikorps in the 1920 s. ${ }^{162}$ Some seem to have been relatively unaffected by acts of violence and returned untroubled to their families. ${ }^{163}$ The majority, however, had been disturbed or, even, damaged by what they had experienced. Exactly how these soldiers coped with demobilization - their private tribulations and joys - is much less well known. 
${ }^{1}$ There is now an extensive literature on demobilization and reintegration: see M. Edele and R. Gerwarth (eds.), 'The limits of demobilization', Journal of Contemporary History, 50 (2015), special issue; R. Bessel, Germany after the First World War (Oxford, 1993); J. Dülffer und G. Krumeich (eds.), Der verlorene Frieden. Politik und Kriegskultur nach 1918 (Essen, 2002); B. Ziemann, 'Germany after the First World War - a violent society? Results and implications of recent research on Weimar Germany', Journal of Modern European History, 1 (2003), pp. 80-95; D. Schumann, Political Violence in the Weimar Republic, 1918-1933 (New York, 2009).

${ }^{2}$ E. M. Remarque, All Quiet on the Western Front (London, 1994), p. 97. See also W. Flex, Der Wanderer zwischen beiden Welten (Munich, 1916).

${ }^{3}$ E. M. Remarque, All Quiet on the Western Front (London, 1994), trans. B. Murdoch, p. 186.

${ }^{4}$ E. Jünger, The Storm of Steel (London, 1929), 317. In Stahlgewittern was first published in German in 1920. On Jünger's changing attitudes, see T. Nevin, Ernst Jünger and Germany: Into the Abyss, 1914-1945 (Durham, NC, 1996), pp. 39-74; M. Meyer, Ernst Jünger (Munich, 1993), pp. 15-98.

5 J. Bourke, An Intimate History of Killing: Face to Face Killing in Twentieth-Century Warfare (London, 1999), p. 5.

${ }^{6}$ Ibid., p. 6.

${ }^{7}$ F. Dahn, Erinnerungen (Leipzig, 1894), IV, p. 335.

${ }^{8}$ Ibid.

${ }^{9}$ Cited in S. Hynes, The Soldiers' Tale: Bearing Witness to Modern War (New York, 1997), p. 40.

${ }^{10}$ D. Lloyd George, 'A Nation's Thanks', 29 Oct. 1917, cited in J. Bourke, An Intimate History of Killing, p. 47.

${ }^{11}$ H. de Man, The Remaking of Mind: A Soldier's Thoughts on War and Reconstruction (London, 1920), pp. 198-199, cited ibid., p. 19.

12 Ibid., p. 64.

${ }^{13}$ Ibid., p. 65, citing S.L.A. Marshall, Men Against Fire: The Problem of Battle Command in Future War (New York, 1947), pp. 44-8. 
${ }^{14}$ J. Bourke, An Intimate History of Killing, p. 78.

${ }^{15}$ Ibid., pp. 100, 146. S.L.A. Stouffer (ed.), The American Soldier (Princeton, 1949), 2 vols., concluded amongst other things that, 'counter-intuitively', rural troops did not become better soldiers than urban ones and that soldiers did not become better with experience, in fact peaking after three or four months. See also J. P. Ryan, Samuel Stouffer and the GI Survey: Sociologists and Soldiers during the Second World War (Knoxville, TE, 2013), p. 76, who reveals how common discussions of what would come to be labelled post-traumatic stress disorder were during the war itself.

${ }^{16}$ J. Bourke, An Intimate History of Killing, pp. 100, 146.

${ }^{17}$ N. Elias, The Civilising Process: The History of Manners (New York, 1978), I, pp. 193, 200.

${ }^{18}$ S. Freud, 'Thoughts for the times on war and death', in J. Strachey (ed.), The Standard Edition of the Complete Psychological Works of Sigmund Freud (London, 1957), XIV, p. 277. See especially D. Pick, War Machine: The Rationalisation of Slaughter in the Modern Age (New Haven, 1993), pp. 14-19, 239-55.

19 Ibid., p. 295.

${ }^{20}$ Bourke, An Intimate History of Killing, pp. 360, 364: 'as this book has attempted to emphasize, warfare was as much about the business of sacrificing others as it was about being sacrificed. For many men and women, this was what made it "a lovely war".'

${ }^{21}$ N. Elias, The Civilising Process, I, p. 204.

22 Ibid., pp. 177, 202.

${ }^{23}$ Ibid., p. 196.

24 Ibid.

${ }^{25}$ Cited in S. Hynes, The Soldiers' Tale, pp. 39-40.

26 Ibid.

27 Ibid.

${ }^{28}$ For further literature, see A. Watson, Enduring the Great War: Combat, Morale and Collapse in the British and German Armies, 1914-1918 (Cambridge, 2008), and idem, Ring of Steel: Germany and Austria in World War I (London, 2014). On the Eastern Front, which has been overshadowed until recently by work on the Western Front and which witnessed different conditions, see V.J. Liulevicius, War Land on the Eastern 
Front: Culture, National Identity and German Occupation in World War I (Cambridge, 2000); J. Böhler et al. (eds.), Legacies of Violence: Eastern Europe's First World War (Munich, 2014); D. R. Stone, The Russian Army in the Great War: The Eastern Front, 1914-1917 (Lawrence, KS, 2015); G. Irving Root, Battles East: A History of the Eastern Front in the First World War (Baltimore, 2007).

${ }^{29}$ The historiography on war, art and literature is vast, with J. Winter, Sites of Memory, Sites of Mourning: The Great War in European Cultural History (Cambridge, 1995), and P. Fussell, The Great War and Modern Memory (Oxford, 1975) remaining the classic texts.

${ }^{30}$ E. M. Remarque, All Quiet on the Western Front, p. 40.

${ }^{31}$ Ibid., p. 63.

32 Ibid.

${ }^{33}$ S. Hynes, The Soldiers' Tale, xi.

${ }^{34}$ A. Kramer, Dynamic of Destruction: Culture and Mass Killing in the First World War (Oxford, 2007), p. 5.

35 The overall total of casualties was, of course, higher in 1914, numbering about 500,000 on the western front and about a third as many on the eastern front: R. Chickering, Imperial Germany and the Great War, 1914-1918 (Cambridge, 1998), p. 30. H. Herwig, The Marne 1914: The Opening of World War I and the Battle that Changed the World (New York, 2009), pp. 112, 117, 168, 315-316; T. Zuber, The Battle of the Frontiers: Ardennes 1914 (Stroud, 2009), pp. 123-262; E.D. Brose, The Kaiser's Army: The Politics of Military Technology during the Machine Age, 1870-1918 (Oxford, 2001), p. 200. Großer Generalstab, The Franco-German War 1870-1871 (London, 1874-84), I, appendix 24, used by Howard, Franco-German War, pp. 161, 181, noting that the General Staff increased the figures for Mars-la-Tour, after investigating French sources. ${ }^{36}$ The figures for the First World War are taken from R.W. Whalen, German Victims of the Great War, 1914-1939 (Ithaca, 1984), p. 55.

${ }^{37}$ E. Arnold (ed.), Feldbriefe von Georg Heinrich Rindfleisch, p. 5.

${ }^{38}$ Vatke, Feldpostbriefe aus Frankreich 1870-71 (Berlin, 1871), p. 5.

${ }^{39}$ E. Pfleiderer, Erinnerungen und Erfahrungen eines Feldpredigers, p. 76. 
${ }^{40}$ F. Blumenfeld, 24 Sept. 1914, in P. Witkop (ed.), German Students' War Letters (London, 1929), p. 19.

${ }^{41}$ W. Limmer, 7 Aug. 1914, ibid., p. 2.

${ }^{42}$ W. Freiherr v. Richthofen, Zurückgehaltenes und Unterdrücktes aus vier Kriegsjahren (Berlin, n. d.), p. 24.

${ }^{43}$ Cited in W. Kruse, 'Kriegsbegeisterung? Zur Massenstimmung bei Kriegsbeginn', in idem (ed.), Eine Welt von Feinden. Der Große Krieg 1914-1918 (Frankfurt, 1997), p. 164. See also idem, Krieg und nationale Integration. Eine Neuinterpretation des sozialdemokratischen Burgfriedenschlusses 1914/1915 (Essen, 1993); J. Verhey, The Spirit of 1914: Militarism, Myth and Mobilization in Germany (Cambridge, 2000).

${ }^{44}$ Cited in B. Ziemann, War Experiences in Rural Germany, 1914-1923 (Oxford, 2007), p. 18.

${ }^{45}$ C. C. Rückert, Mit dem Tornister. Ungeschminkte Feldzugs-Erinnerungen eines Infanteristen aus dem Jahre 1870 (Frankfurt, 1912), p. 24. See also K. Schürmann, Selbsterlebtes. Kriegserinnerungen eines Volksschullehrers (Remscheid, 1895), p. 4; F. Schäfer, 'Aus dem Tagebuch von 1870/71', Feldpostbriefe, Universitäts- und Landesbibliothek, Bonn. Karl Klein, Fröschweiler Chronik. Kriegs- und Friedensbilder aus dem Jahr 1870 (Munich, 1905), p. 3, reported widespread fear, as well as strong feelings against Prussia, in French Alsace at the start of the war.

${ }^{46}$ L. Heiners, 'Tagebuch und Erlebnisse aus meiner Dienstziet beim Königin Augusta Garde Grenadier Reg. No. 4', Feldpostbriefe, Universitäts- und Landesbibliothek, Bonn. ${ }^{47}$ W. v. Klenck, cited in A. Seyferth, Die Heimatfront 1870/71. Wirtschaft und Gesellschaft im deutsch-französischen Krieg (Paderborn, 2007), 25; L. Pietsch, Von Berlin bis Paris. Kriegsbilder 1870-1871 (Berlin, 1871), pp. 3-4.

48 J. Hesse, 'Notiz-Buch', Feldpostbriefe, Universitäts- und Landesbibliothek, Bonn. For a similar account, see F. Ludwig to his parents and wife, 5 Aug. 1870, Hessisches Staatsarchiv, Marburg: 'Wir sind am 4ten August über die Grenze gerückt, des Nachts um zwei Uhr, im furchtbaren Regenwetter des morgens kamen wier an den Feind um 9 Uhr und hat gedauert bis den Mittag 4 Uhr, in welcher die Franzosen geschlagen worden sind. Von unser Companie sind drei gefallen, ich bin aber noch gesund und unverletzt.' ${ }^{49}$ H. Lohmanns, 2 Aug. 1870, Feldpostbriefe, Universitäts- und Landesbibliothek, Bonn. 
${ }^{50}$ E. Metsch, Meine Erlebnisse als Einjährig-Freiwilliger beim $k$. . . InfanterieLeibregiment im Kriege gegen Frankreich 1870-71 (Munich, 1871), pp. 7-9.

${ }^{51}$ F. Kühnhauser, Kriegs-Erinnerungen, pp. 5, 27.

52 Ibid.

53 Ibid.

${ }^{54}$ E. Metsch, Meine Erlebnisse, p. 6.

55 Ibid.

${ }^{56}$ W. Limmer, 7 Aug. 1914, in Witkop (ed.), German Students' War Letters, pp. 2-3.

${ }^{57}$ Ibid., p. 2.

${ }^{58}$ Ibid., p. 3.

59 Ibid.

60 Ibid.

${ }^{61}$ Ibid., p. 4.

62 Ibid.

${ }^{63}$ A. Schicht, 11 Aug. and 8 Sept. 1914, in O. Häring (ed.), Ein Held der Garde. Meines Neffen Kriegstagebuch und Briefe aus dem Felde (Altenburg, 1917), pp. 4, 16.

${ }^{64}$ Ibid., p. 16.

${ }^{65}$ R. J. Evans (ed.), Kneipengespräche im Kaiserreich. Die Stimmungsberichte der Hamburger Politischen Polizei 1892-1914 (Reinbek, 1989), p. 415.

${ }^{66}$ Ibid. R. J. Evans, 'Proletarian mentalities: pub conversations in Hamburg', in idem, Proletarians and Politics: Socialism, Protest and Working Class in Germany before the First World War (London, 1990), p. 183: for some workers, at best, it was 'all the same to me, whether I die at work or for the fatherland, and you're going as well as me, I tell you.'

${ }^{67}$ Cited in V. Ullrich, 'Kriegsalltag. Zur inneren Revolutionierung der Wilhelmischen Gesellschaft', in W. Michalka (ed.), Der Erste Weltkrieg. Wirkung, Wahrnehmung, Analyse (Munich, 1994), p. 604. See also V. Ullrich, Kriegsalltag. Hamburg im Ersten Weltkrieg (Cologne, 1982).

${ }^{68}$ F. Worblewski to his sister, 1 Aug. 1914, Feldpost 1914-1918, Museum für Kommunikation, Berlin. 
${ }^{69}$ D. Stevenson, 1914-1918: The History of the First World War (London, 2004), p. 49. Idem, 'War by timetable? The railway race before 1914', Past and Present, 162 (1999), pp. 163-194.

${ }^{70}$ J. Lauth to his wife, 21 Aug. 1914, Feldpost 1914-1918, Museum für Kommunikation, Berlin.

${ }^{71}$ A. Hitler, cited in T. Weber, Hitler's First War (Oxford, 2010), p. 32.

${ }^{72}$ M. Böhme (ed.), Kriegsbriefe Familie Wimmel (Dresden, 1915), p. 123.

${ }^{73}$ L. to K. Weber, 10 Sept. 1914, in H. Schöttler (ed.), 1914 in Briefen und

Feldpostbriefen (Leipzig, 1914), p. 99.

${ }^{74}$ R. Martin, Kriegserinnerungen, pp. 175-177.

${ }^{75}$ E. Metsch, Meine Erlebnisse, pp. 11-13.

76 Ibid.

${ }^{77}$ Ibid.

78 Ibid.

${ }^{79}$ Ibid., p. 16.

${ }^{80}$ G. Boschen, Kriegserinnerungen, 33; Friedrich Karl, Denkwürdigkeiten, II, p. 225.

${ }^{81}$ C. L. Hänel, Bei den Fahnen, p. 20.

${ }^{82}$ Ibid., p. 22.

83 Ibid., pp. 23, 25-6.

${ }^{84}$ L. Heiners, 'Tagebuch und Erlebnisse aus meiner Dienstziet beim Königin Augusta Garde Grenadier Reg. No. 4', Feldpostbriefe, Universitäts- und Landesbibliothek, Bonn. ${ }^{85}$ Ibid., p. 28.

${ }^{86}$ Ibid.

87 Ibid.

88 Ibid.

${ }^{89}$ Ibid., p. 27.

90 Ibid.

${ }^{91}$ Ibid.

${ }^{92}$ Ibid., p. 28. 
93 Diary of Lieutenant W., cited in W. Förster (ed.), Wir Kämpfer im Weltkrieg.

Feldzugsbriefe und Kriegstagebücher von Frontkämpfern aus dem Material des Reichsarchivs (Berlin, 1929), p. 3.

94 O. Daumiller, 2 Nov. 1914, cited in T. Weber, Hitler's First War, p. 48.

${ }^{95}$ B. Berger to his wife, 13 Aug. 1914, in H. Schöttler (ed.), 1914 in Briefen und Feldpostbriefen (Leipzig, 1914), p. 54.

96 A. Schicht, diary entry, 8 Sept. 1914, in Häring (ed.), Ein Held der Garde, p/ 16.

97 Ibid.

98 Idem, 9 Sept. 1914, ibid., p. 18.

99 Ibid.

${ }^{100}$ Ibid., p. 19.

${ }^{101}$ Ibid., pp. 43, 67.

${ }^{102}$ Schupp (ed.), Eines Freiburger Theologen Kriegstagebücher 1914/18, p. 25.

${ }^{103}$ W. Tharann, Aus dem Kriegstagebuch eines Gefallenen (Leipzig, 1918), p. 24.

${ }^{104}$ Ibid., p. 25.

105 Ibid.

${ }^{106}$ Ibid., p. 51.

${ }^{107}$ Ibid.

108 Ibid.

${ }^{109}$ Ibid.

${ }^{110}$ Ibid., p. 10.

${ }^{111}$ H. Maibaum to his parents, 19 Oct. 1914, in M. Boehme (ed.), Kriegsbriefe der Familie Wimmel, p. 123.

112 Ibid., p. 46.

${ }^{113}$ Leutnant B., in W. Förster (ed.), Wir Kämpfer im Weltkrieg, p. 149.

114 Ibid.

${ }^{115}$ Ute Frevert, A Nation in Barracks: Modern Germany, Military Conscription and Civil Society (Oxford, 2004), p. 180, makes this case: 'Despite the cultural ban on killing being officially suspended in wartime, its impact continued unabated in both war memoirs and the preparation of war.' Heidi Mehrkens, Statuswechsel. Kriegserfahrung und nationale Wahrnehmung im Deutsch-Französischen Krieg 1870/71 (Essen, 2008), p. 
60 , links the paucity of references to the absence of strongly defined images of the enemy in 1870-71, yet this was less the case at the start of the First World War.

${ }^{116}$ Christine Krüger, 'Sind wir denn nicht Brüder?' Deutsche Juden im nationalen Krieg 1870/71 (Paderborn, 2006), p. 240, amongst others, shows how troops could speak quite openly about killing, even in 1870-71.

${ }^{117}$ K. Cramer, The Thirty Years' War and German Memory in the Nineteenth Century (Lincoln, NE, 2007); C. Clark, 'The Wars of Liberation in Prussian memory: reflections of the memorialization of war in early nineteenth-century Germany', Journal of Modern History, 68 (1996), pp. 550-576. For a fuller list of works, see M. Hewitson, 'On war and peace: German conceptions of conflict, 1792-1815', Historical Journal, 57 (2014), pp. 447-483.

${ }^{118}$ A. Fitze, Kriegstagebuch eines einjährig-freiwilligen Ulanen aus dem Feldzuge 1870/71 (Rathenow, 1887), p. 12. See also C. Schepers, Bilder und Eindrücke, p. 55, who shielded his readers from the worst sights of a field hospital: 'Will the reader take a tour through my hospital? He doesn't need to fear. He won't have to see terrible things.' This, of course, was also to acknowledge that readers expected to come across such things. ${ }^{119}$ Fester, Jugenderinnerungen, p. 44.

${ }^{120}$ A. Hecker, Ernstes und Heiteres aus dem Kriegstagebuche eines sächsischen Oberjägers 1870/71 (Dresden, 1895), pp. 22-23. See also B. Berlit (ed.), Vor Paris und an der Loire 1870 und 1871 (Cassel, 1872); Maizier, Tagebuch aus dem französischen Kriege für die Zeit von Ausmarsch bis zur Waffenruhe (Magdeburg, 1896); H. SeelmannEggebert, Feldpostbriefe aus dem Kriegsjahre 1870 (Colberg, 1872); H. Abeken, Ein schlichtes Leben in bewegter Zeit, $3^{\text {rd }}$ rev. edn. (Berlin, 1904); T. Niedermeyer, Aus meinem Tagebuche: Erlebnisse und Schilderungen aus dem Kriege gegen Frankreich 1870-71 (Hanover, 1871).

${ }^{121}$ H. Bonsack, Kriegserlebnisse eines Fünfundneunzigers im Feldzug gegen Frankreich 1870-1871 (Gotha, 1906), p. 17.

${ }^{122}$ Bornemann, Kriegs-Tagebuch, p. 12.

${ }^{123}$ D. v. Lassberg, Mein Kriegstagebuch, pp. 1, 4, 13.

${ }^{124}$ Ibid., p. 15.

${ }^{125}$ Ibid., pp. 16-17. 
${ }^{126}$ Ibid., p. 23.

${ }^{127}$ Ibid., pp. 55, 57.

${ }^{128}$ K. v. Einsiedel, Tagebuchblätter aus dem deutsch-französischen Krieg (Berlin, 1907), p. 82 .

${ }^{129}$ Ibid., p. 85.

${ }^{130}$ Ibid., p. 80.

${ }^{131}$ F. v. Frankenberg, Kriegstagebücher von 1866 und 1870/71 (Stuttgart, 1896), p. 166.

132 Ibid., p. 169.

${ }^{133}$ J. Schupp (ed.), Eines Freiburger Theologen Kriegstagebücher 1914/18, p. 25. See

also E. Baumann, Mit der Garde im Osten. Feldbriefe und Kriegstagebuchblätter (Halle, 1916), p. 16.

${ }^{134}$ H. v. Koenigswald (ed.), Stirb und Werde. Aus Briefen und Kriegstagebuchblättern des Leutnants Bernhard von der Marwitz (Breslau, n. d.), p. 101.

${ }^{135}$ B. Ziegler, 14 Sept. 1914, in P. Witkop (ed.), German Students' War Letters, 5.

${ }^{136}$ H. Müller, 11 Mar. 1916, ibid., pp. 280-281.

${ }^{137}$ H. Zschuppe, 25 Oct. 1916, ibid., p. 365.

${ }^{138}$ J. v. Winterfeldt, Tagebuchblätter und Briefe während des grossen Krieges (Munich, 1917), pp. 131-2.

139 Ibid.

${ }^{140}$ Unteroffizier V., autumn 1914, in Förster (ed.), Wir Kämpfer, p. 99.

${ }^{141}$ Schupp (ed.), Eines Freiburger Theologen Kriegstagebücher, p. 97.

142 Tharann (ed.), Aus dem Kriegstagebuch, p. 105.

${ }^{143}$ F.G. Steinbrecher, in Witkop (ed.), German Students' War Letters, pp. 320-3.

${ }^{144}$ E. Leed, No Man's Land: Combat and Identity in World War I (Cambridge, 1979) gives the figure of 4 percent for the United Kingdom. The German figure is given in Chickering, Imperial Germany and the Great War, p. 99.

${ }^{145}$ See Ulrich, Die Augenzeugen, pp. 191-226.

${ }^{146}$ D. Vallendar to L. Wimmel, 18 Dec. 1914, cited in M. Boehme (ed.), Kriegsbriefe der Familie Wimmel (Dresden, 1915), p. 169.

${ }^{147}$ W. Pfuhl, 17 Nov. 1916, cited in Ulrich, Die Augenzeugen, p. 210. 
${ }^{148}$ See especially Ziemann, War Experiences in Rural Germany, pp. 29-72, and Watson, Enduring the Great War, pp. 85-107.

${ }^{149}$ F. Dahn, Erinnerungen (Leipzig, 1894), IV, pp. 590-594.

${ }^{150}$ Ibid., p. 445.

151 Ibid., p. 594.

152 Ibid., pp. 444-445.

${ }^{153}$ Ibid., pp. 529-530.

154 Ibid., pp. 569-570.

${ }^{155}$ This willingness was no doubt also affected by the fact that post-war authors were writing after a defeat, in contrast to the vantage point of their predecessors after 1870-71. The similarity of accounts in victorious states and in defeated ones in the 1920s hints, however, that a more fundamental shift had occurred over the intervening decades, in many cases overriding political and national differences.

${ }^{156}$ Grenadier V., cited in Förster (ed.), Wir Kämpfer, p. 365.

${ }^{157}$ E.M. Remarque, All Quiet on the Western Front, p. 100.

${ }^{158}$ Ibid., pp. 86-87.

${ }^{159}$ Ibid., pp. 205-207.

${ }^{160}$ R.E. Walton, 'Memories from the edge of the abyss: evaluating the oral accounts of World War II veterans', Oral History Review, 37 (2010), pp. 18-34.

${ }^{161}$ Kühlich, Die Deutschen Soldaten im Krieg von 1870/71, pp. 207-209. The Feldpost effectively started a regular service for the mass of soldiers in 1870: it had only carried about 30,000 letters in 1866. For a reference to the 'dark sides' of war, which were common, see Lassberg, Mein Kriegstagebuch, p. 80.

${ }^{162}$ E. Michels, Deutsche in der Fremdenlegion 1870-1965 (Paderborn, 1999); K. Theweleit, Male Fantasies (Cambridge, 1987-89), 2 vols.; R. Gerwarth and J. Horne (eds.), War in Peace: Paramilitary Violence in Europe after the Great War (Oxford, 2012); R. Gerwarth, 'Vectors of violence: paramilitarism in Europe after the Great War, 1917-1923', Journal of Modern History, 83 (2011), pp. 489-512; H.W. Koch, Der deutsche Bürgerkrieg. Eine Geschichte der deutschen und österreichischen Freikorps 1918-1923 (Hamburg, 1978).

${ }^{163}$ Bourke, An Intimate History of Killing, pp. 335-57. 